\title{
Pathogen-derived Resistance to Tomato Spotted Wilt Virus in Transgenic Tomato and Tobacco Plants
}

\author{
Olga Fedorowicz and Grzegorz Bartoszewski \\ Department of Plant Genetics Breeding and Biotechnology, Faculty of Horticulture and Landscape \\ Architecture, Warsaw Agricultural University, Nowoursynowska 166, 02-787 Warsaw, Poland
}

Maria Kamińska

Research Institute of Pomology and Floriculture, Pomologiczna 18, 96-100 Skierniewice, Poland

\author{
Pravda Stoeva \\ AgroBioInstitute, 8 Dragan Tzankov Boulevard, 1164 Sofia, Bulgaria
}

\author{
Katarzyna Niemirowicz-Szczytt ${ }^{1}$ \\ Department of Plant Genetics Breeding and Biotechnology, Faculty of Horticulture and Landscape \\ Architecture, Warsaw Agricultural University, Nowoursynowska 166, 02-787 Warsaw, Poland
}

\begin{abstract}
ADDITIONAL INDEX WORDS. nucleoprotein gene-mediated resistance, post-transcriptional gene silencing, tospovirus, TSWV
ABSTRACT. This study was undertaken to remedy significant yield losses in commercial tomato (Lycopersicon esculentum Mill.) and tobacco (Nicotiana tabacum L.) production caused by tomato spotted wilt virus (TSWV). One of the possible sources of resistance can be incorporation into the host plant of a viral nucleoprotein $(N)$ gene by Agrobacterium-mediated transformation. Twelve primary transformants of tomato and 141 of tobacco were analyzed for the expression of the $N$ gene and for resistance to the TSWV infection. The tests have demonstrated that transgenic plants were protected against virus infection irrespective of whether or not they contained detectable levels of the translational product.
\end{abstract}

Tomato spotted wilt virus (TSWV) causes one of the most severe diseases affecting tomato and brings about significant yield losses. At present, TSWV is spread all over the world and under diverse environmental conditions infects more than 850 plant species belonging to over 82 botanical families, including such important crops as tomato, tobacco, pepper (Capsicum annuum L.), potato (Solanum tuberosum L.), and lettuce (Lactuca sativa L.) (Goldbach and Peters, 1994; Prins and Goldbach, 1998). TSWV is a thrips-transmitted RNA virus, classified as genus Tospovirus in family Bunyaviridae (Francki and Hatta, 1981; Wijkamp et al., 1993). It was reported first in Australia in 1906 (Sakimura, 1962) in Europe (Smith, 1932), and in Poland (Jankowski et al., 1963), gradually becoming one of the major threats to fruit production under greenhouse conditions (Kaminska and Korbin, 1994).

The virus genome consists of three single-stranded linear RNA molecules: L, M, and S, which form pseudo-circular particles tightly complexed with the viral $28.8 \mathrm{kDa}$ nucleoprotein $(N)$. The L RNA [8.9 kilobases (kb)] is of negative polarity, while M $(5.4 \mathrm{~kb})$ and $\mathrm{S}(2.9 \mathrm{~kb})$ RNAs are of ambisense polarity. The $\mathrm{S}$ RNA encodes the viral $\mathrm{N}$ protein in viral complementary sense (de Haan et al., 1990). The management of the TSWV disease requires chemical protection, culture practices and development

Received for publication 13 Nov. 2003. Accepted for publication 15 July 2004. This work was partially supported by the Polish State Committee for Scientific Research Grant No. 6PO6A01820. Tomato breeding line KR was kindly provided by Dr. Ewa Żukowska, PHRO Krzeszowice Seed Co., Poland.

${ }^{1}$ To whom reprint requests should be addressed. E-mail address: niemirowicz@alpha.sggw.waw.pl of resistant varieties. The sources of genetic resistance in the genus Lycopersicon Mill. are not always effective, especially under strong infection pressure (Rosello et al., 1996). Since 1991, several reports have confirmed that engineered pathogen-derived resistance can be exploited successfully for TSWV by expressing its $N$ gene in transgenic plants (Gielen et al., 1991; Kim et al., 1994; MacKenzie and Elis, 1992; Pang et al., 1992; Stoeva et al., 1998; Ultzen et al., 1995). Further studies revealed that the transcript of the nucleoprotein gene mediates the resistance to the homologous and very closely related isolates of TSWV (de Haan et al., 1992; Pang et al., 1993; Vaira et al., 1995), while the nucleoprotein protection mechanism accounts for a broaderspectrum resistance that extends to distantly related tospoviruses although at a very low level (Pang et al., 1993; Vaira et al., 1995). Pang et al. (1996) reported on the protection against TSWV in transgenic lettuce expressing the nucleoprotein gene of the lettuce isolate of the virus via the $N$ gene silencing mechanism or via a high level of accumulation of the transgenic $\mathrm{N}$ protein.

In this report we will show a high level of resistance to the TSWV infection obtained by the transformation of tomato and tobacco plants with the $N$ gene of a Bulgarian TSWV isolate. The inheritance of the pathogen-derived resistance to TSWV was confirmed in two generations. Molecular analysis of the transgene expression pattern indicated that the engineered resistance to TSWV infection could be based on two different mechanisms: RNA-dependent (post-transcriptional silencing) or protein-dependent (protein accumulation). The paper gives some new information about the pathogen-derived resistance to TSWV showing that viral nucleoprotein expressed in plant tissue can cause high level of resistance. 


\section{Materials and Methods}

Plant material and Plant expression vectors. Three accessions of tomato: a breeding line nor carrying non-ripening (nor) mutation (Seroczyńska et al., 1998), a breeding line KR, cultivar Potentat, and tobacco cultivar Petit Havana were used in the Agrobacterium-mediated [Agrobacterium tumefaciens (Smith and Town) Conn.] transformation experiments. Transgenic plants were produced by the use of the chimerical gene cassette constructed by Stoeva et al. (1998). It consisted of a 850-base-pair (bp) fragment comprising the full-length coding sequence of the nucleoprotein $(N)$ gene from the Bulgarian L3 isolate of TSWV under two cauliflower mosaic virus (CaMV) 35S promoter sequences fused with untranslated leader sequence (UTR) from the plum pox virus (PPV), and the $35 \mathrm{~S}$ CaMV terminator sequence (Stoeva et al., 1998). The cassette was cloned into the HindIII site in two plant expression vectors: pLX222 (Landsmann et al., 1988) and pCAMBIA-2300 (GenBankAccession No.AF234315; CAMBIA, Canberra, Australia). The resulting binary plasmids pXEL (Stoeva et al., 1998) and pCN were transferred into $A$. tumefaciens strain GV3101:MP90 (Koncz and Schell, 1986) by electroporation.

AGROBACTERIUM TUMEFACIENS-MEDIATED TRANSFORMATION. TOmato transformation was performed as described by McCormick (1991) with modifications (Bartoszewski et al., 1996). Tobacco transformation was performed as described by Horsch et al. (1985). Tomato cotyledon explants and tobacco leaf disks were co-cultivated with A. tumefaciens strain GV3101:MP90 carrying either the pXEL or pCN plasmids. The shoots were regenerated on the MS medium (Murashige and Skoog, 1962) supplemented with adequate phytohormones $\left(2 \mathrm{mg} \cdot \mathrm{dm}^{-3}\right.$ zeatin and $0.02 \mathrm{mg} \cdot \mathrm{dm}^{-3}$ IAA for tomato and $1 \mathrm{mg} \cdot \mathrm{dm}^{-3}$ BAP and $1.0 \mathrm{mg} \cdot \mathrm{dm}^{-3} \mathrm{NAA}$ for tobacco regeneration) and antibiotics $\left(75 \mathrm{mg} \cdot \mathrm{dm}^{-3}\right.$ kanamycin sulfate and $400 \mathrm{mg} \cdot \mathrm{dm}^{-3}$ carbenicillin). Regenerated shoots were rooted on the MS medium with the same antibiotics as above and supplemented with $0.2 \mathrm{mg} \cdot \mathrm{dm}^{-3}$ IAA for the tomato and 0.1 $\mathrm{mg} \cdot \mathrm{dm}^{-3}$ NAA for the tobacco shoots. Primary transgenic plants were grown under greenhouse conditions.

ANALYSIS OF TRANSGENIC PLANTS. Southern-blot analyses were performed on $\mathrm{R}_{0}$ plants according to the Sambrook et al. (1989) procedure. DNA $(12 \mu \mathrm{g})$ extracted from leaf material (Doyle and Doyle, 1990) was digested with HindIII or DraI and fractioned by electrophoresis in $0.8 \%$ agarose gels. HindIII restriction enzyme released an internal T-DNA fragment containing the TSWV chimeric $N$ gene, while there was no DraI restriction site in the T-DNA insert. Fractioned DNA was blotted to Zeta-Probe GT membrane (Bio-Rad, Hercules, Calif.) and hybridized to a ${ }^{32} \mathrm{P}-$ labeled 500-bp fragment of the $N$ gene. Labeling was performed using Random Primed DNALabeling Kit(Boehringer Mannheim, Indianapolis, Ind.).

TSWV INOCULATION AND SCREENING FOR RESISTANCE. Transgenic plants were screened for resistance in both $\mathrm{T}_{1}$ and $\mathrm{T}_{2}$ generations during two growing seasons (20 kanamycin resistant progenies from each tested plant). Plants were grown under controlled greenhouse conditions. The plants were mechanically inoculated with the virus according to Rusinowski et al. (2002). Two Polish TSWV strains were used for testing: C from Columnea L. and B from Catharanthus G. Don. The inoculation was repeated twice within 2-3 weeks. Plants showing any of the resistant phenotype two weeks after the last inoculation were checked for the presence of TSWV by the indicator (Nicotiana rustica L.) plant inoculation and by double-antibody sandwich enzyme-linked immunosorbent assay (DAS-ELISA).

TransGene EXPRESSION ANALYSIS. Northern-blot analysis was done on $\mathrm{R}_{0}$ transgenic plants according to the Sambrook et al. (1989) procedure. Total RNA was extracted from the leaves as described by Chomczynski (1993) and separated on a $1.2 \%$ formaldehyde agarose gel $(20 \mu \mathrm{g} / \mathrm{lane})$. Fractionated RNA was blotted to Zeta-Probe GT membrane (Bio-Rad) and hybridized to a ${ }^{32} \mathrm{P}$ labeled 500-bp fragment of the $N$ gene. Labeling was performed using Random Primed DNALabeling Kit(Boehringer Mannheim). Hybridization, washings and autoradiography were performed as per membrane manufacturer's protocol (Bio-Rad).

DAS-ELISA was applied for a serological detection of the viral nucleoprotein by using polyclonal rabbit antibodies (Agdia, Elkhart, Ind.).

ISOLATION OF NUCLEI AND NUCLEAR RUN-ON TRANSCRIPTION ASSAY. Plant material (5 g) was ground to a fine powder in liquid nitrogen, suspended in $40 \mathrm{~mL}$ of the extraction buffer (chemical constitution according to Dehio and Schell, 1994), supplemented with $1 \%$ Triton X-100 (Sigma, St. Louis), and briefly homogenized. After filtration through a 50- $\mu$ m nylon mesh, the filtrate was centrifuged for $5 \mathrm{~min}$ at $1500 \mathrm{~g}_{\mathrm{n}}$. The pellet was resuspended in $2 \mathrm{~mL}$ of the same buffer and loaded on a gradient consisting of 6-mL layers of $80 \%$ and $35 \%$ (v/v) Percoll (Sigma) in extraction buffer, followed by a centrifugation for $15 \mathrm{~min}$ at $1000 \mathrm{~g}_{\mathrm{n}}$. Nuclei were collected from the interface of the $80 \%$ and $35 \%$ layers and diluted to $35 \mathrm{~mL}$ in the same buffer. Six milliliters of $35 \%$ Percoll was then laid under the pellet. After centrifugation, the nuclei-enriched pellet was resuspended in approximately three volumes of the nuclear storage buffer (Dehio and Schell, 1994). Aliquots of nuclei were counted in a Neubauer chamber under a fluorescence microscope after staining with DAPI solution (Partec, Münster, Germany). The run-on assay utilized $10^{6}$ (in 50 $\mu \mathrm{L})$ isolated nuclei and was conducted as described by Dehio and Schell (1994). The generated $\mathrm{P}^{32}$-labeled transcripts were used for hybridization with identical filters containing $0.2 \mu \mathrm{g}$ of DNA of a 500-bp fragment of nucleoproteine $N$ gene, $0.2 \mu \mathrm{g}$ of DNA of a 350-bp nptII gene, and $0.2 \mu \mathrm{g}$ of DNA of the 400-bp 3'-end of $25 \mathrm{~S}$ rRNA sequence. Hybridization and washing conditions were as described by Sambrook et al. (1989).

\section{Results}

ANALYSIS OF TRANSGENIC PLANTS. The A.tumefaciens-mediated transformation yielded a total of 12 tomato and 141 tobacco primary transformants. All these plants had proper ploidy levels and showed normal development, except five tomato plants that did not produce seeds. All transformants were studied for the transgene integration patterns, transgene expression, and were tested for resistance (Tables 1 and 2). Southern-blot analysis revealed different patterns of integration (one to three inserts) in the genomes of analyzed plants. Correct integration of the nucleoprotein gene was observed in eight tomato and 103 tobacco plants. Three tomato and 27 tobacco plants had correct insert and additional inserts of various lengths. One tomato and three tobacco plants showed integration of only shorter sequences, and eight tobacco plants were characterized by only longer sequences.

Testing Transgenic Plants FOR Resistance. All plants that produced seeds for $\mathrm{R}_{1}$ generation (seven tomato and 141 tobacco lines) were tested for resistance to two strains of TSWV (Table 1). This revealed a wide range of responses, from susceptibility 
Table 1. Number of primary transformants and lines resistant to the TSWV infection in the $R_{1}$ and $R_{2}$ generations of tomato and tobacco.

\begin{tabular}{llccc}
\hline & $\begin{array}{c}\text { Expression } \\
\text { vector }\end{array}$ & $\begin{array}{c}\text { No. of } \\
\text { primary } \\
\text { transformants }\end{array}$ & \multicolumn{2}{c}{$\begin{array}{c}\text { No. of resistant lines }(\mathrm{HR}, \mathrm{R}, \text { and LL) } \\
\text { per no. of tested lines }\end{array}$} \\
\cline { 4 - 5 } Tomaty line nor & $\mathrm{pCN}$ & 6 & $\mathrm{R}_{1}$ progeny & $\mathrm{R}_{2}$ progeny \\
\hline Tomato line KR & $\mathrm{pXEL}$ & 1 & $5 / 6$ & $5 / 6$ \\
Tomato 'Potentat' & $\mathrm{pCN}$ & 3 & nay & na \\
Tobacco 'Petit Havana' & pCN & 1 & $1 / 1$ & $1 / 1$ \\
& pXEL & 1 & na & na \\
& pCN & 42 & $5 / 42$ & na \\
& pXEL & 99 & $18 / 99$ & $5 / 10$ \\
\hline
\end{tabular}

${ }^{\mathrm{z}} \mathrm{HR}=$ highly resistant, $\mathrm{LL}=$ locally infected, $\mathrm{R}=$ recovery.

yna $=$ not analyzed.

Table 2. Nucleoprotein gene expression pattern in transgenic tomato and tobacco plants with different resistance phenotype: highly resistant (HR), local infection (LL), delayed (D), recovered (R), and sensitive $(\mathrm{S})$.

\begin{tabular}{|c|c|c|c|c|c|}
\hline $\begin{array}{l}\text { Resistance } \\
\text { phenotype }\end{array}$ & No. of plants & $\begin{array}{c}\text { Transgene } \\
\text { integration } \\
\text { pattern }\end{array}$ & $\begin{array}{l}\text { Expression } \\
\text { of } \\
\text { transcript }\end{array}$ & $\begin{array}{l}\text { Expression } \\
\text { of } \\
\text { N protein }\end{array}$ & $\begin{array}{l}\text { Hypothetical } \\
\text { mechanism of } \\
\text { protection }\end{array}$ \\
\hline HR & 5 & $1-2$ inserts & + & $\begin{array}{l}\text { high or } \\
\text { moderate }\end{array}$ & protein dependent \\
\hline HR & 5 & $\begin{array}{l}\text { more than } 1 \text { insert } \\
\text { or insert of } \\
\text { different lengths }\end{array}$ & - & $\begin{array}{l}\text { absence or } \\
\text { very low }\end{array}$ & RNA dependent \\
\hline LL & 10 & $1-2$ inserts & + & $\begin{array}{l}\text { moderate or } \\
\text { high }\end{array}$ & protein dependent \\
\hline LL & 4 & $\begin{array}{l}\text { more than } 1 \text { insert } \\
\text { or insert of } \\
\text { different lengths }\end{array}$ & - & $\begin{array}{l}\text { absence or } \\
\text { very low }\end{array}$ & RNA dependent \\
\hline $\mathrm{D}$ & 3 & $1-2$ inserts & + & moderate or high & $?$ \\
\hline $\mathrm{D}$ & 6 & $\begin{array}{l}1-2 \text { inserts or } \\
\text { insert of different } \\
\text { lengths }\end{array}$ & - & $\begin{array}{l}\text { absence or } \\
\text { very low }\end{array}$ & RNA dependent \\
\hline $\mathrm{R}$ & 5 & 1 insert & - & absence & RNA dependent \\
\hline $\mathrm{S}$ & 2 & $\begin{array}{l}1-2 \text { inserts or } \\
\text { insert of different } \\
\text { lengths }\end{array}$ & + & moderate or high & --- \\
\hline S & 2 & $1-2$ inserts & - & absence & --- \\
\hline
\end{tabular}

(S), through delayed reaction (D), recovery from infection (R), localized infection (LL), to a complete lack of symptoms (HR). The delayed reaction (D) is defined as the appearance of symptoms on transgenic plants at least $10 \mathrm{~d}$ later than on the control; the term recovery $(\mathrm{R})$ applies to plants that originally showed the infection symptoms but which produced new shoots free of infection symptoms; localized infection (LL) refers to the appearance of mild local symptoms while resistance (HR) is a complete lack of virus invasion.

Resistance (HR) was found in 10 transformed tobacco plants (Fig. 1), local infection (LL) in one transformed tomato and 13 tobacco plants, and the delayed reaction (D) in one tomato and eight tobacco plants. A majority of tomato plants (five) showed the recovery (R) phenotype (Fig. 2).

Plants of the $R_{2}$ generation showed the same reaction as the parents. The control plants that were back-inoculated with the inoculum prepared from the HR plant leaves showed no symptoms of virus infection. The absence of TSWV in the HR plant tissue was confirmed by the negative ELISA test $\left(\mathrm{A}_{405}\right.$ below 0.1$)$. The same result was obtained in the bio- and ELISA tests of $\mathrm{R}$ and
LL plants. Control plants showed symptoms of virus infection following inoculation with the inoculum prepared from the D plants. High ELISA scores (mean $\mathrm{A}_{405}>1.23$ ) confirmed virus presence in the plant tissue.

EXPRESSION OF THE N GENE AND ITS LEVEL OF TRANSCRIPTION. The analyses were conducted on all the plants showing any of the resistant phenotype and additionally on four sensitive transgenic tobacco plants. Northern-blot of the total RNA detected a transcript of the $N$ gene as a single band of the expected size (500 bp) with variable intensity (Fig. 3). The transcript of the $N$ gene was present in five tomato and 27 tobacco plants. Plants that produced correct transcripts of the $N$ gene accumulated virus nucleoprotein on different levels (Fig. 4). The $\mathrm{OD}_{405}$ readings ranged from 0.04 to 2.76. Plants were classified as non-expressors when the readings were below 0.41 , as low-expressors when the readings were between 0.41 and 1.20 , as mid-expressors when $\mathrm{OD}_{405}$ were between 1.20 and 1.90, and as high-expressors when the readings were above 1.9 in accordance with Pang et al. (1996). Of the tobacco plants studied, 14 were classified as high-expressors, seven as mid-expressors, six as low-expressors, 


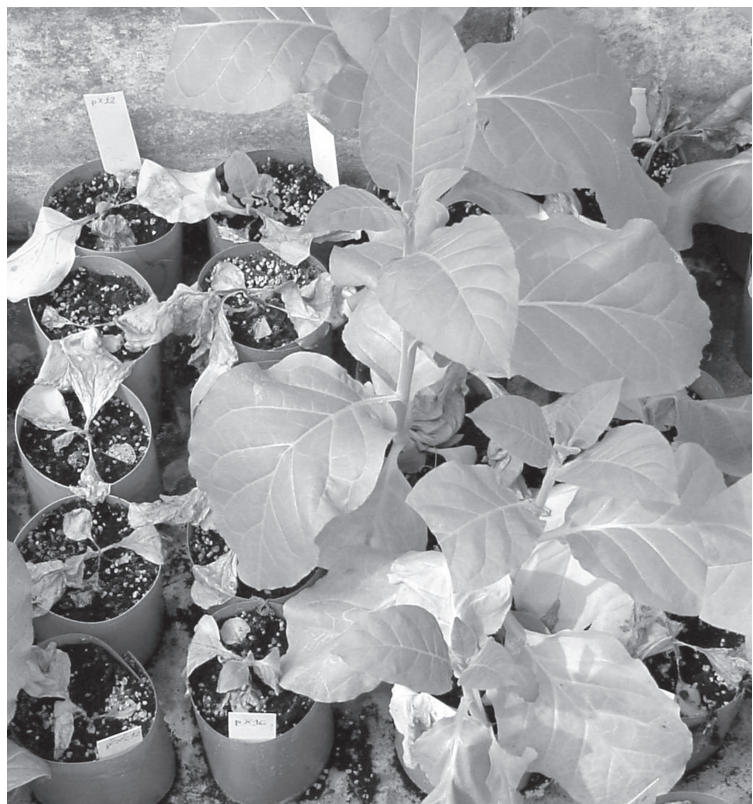

Fig. 1. Transgenic $\mathrm{R}_{1}$ tobacco 'Petit Havana' plants susceptible (left) and resistant (right) to TSWV in greenhouse trials $20 \mathrm{~d}$ after a mechanical inoculation.

and eight as non-expressors. Among the tomato plants, four were low-expressors while eight were non-expressors.

The run-on analysis revealed that the nucleoprotein gene was actively transcribed in plants resistant to the TSWV infection, in those showing high level of the $N$ gene transcript accumulation (expressors) as well as those without any detectable $N$ mRNA (non-expressors) (Fig. 5).

\section{Discussion}

The study showed that tomato and tobacco transformants expressing the sense form of the $N$ gene were resistant to the inoculation with Polish strains of TSWV and that resistance was present irrespective of the nucleoprotein accumulation. Plants with high accumulation as well as those not producing detectable $N$ gene transcripts and protein were resistant to the TSWV infection (Table 2 ). The lack of correlation between resistance and the presence of the nucleoprotein suggests that the engineered resistance can be based on one of two different mechanisms: RNA-dependent (post-transcriptional silencing) resistance or protein-dependent (protein accumulation) resistance.

A majority of the obtained tobacco plants (19) showed high expression of viral protein and exhibited the HR, LL, or D phenotypes, but the amount of the produced protein did not correlate with the level of resistance. The HR phenotype has never been reported before in plants accumulating the virus protein at high levels. Pang et al. (1992) reported that among the progeny of seven transgenic tobacco lines, resistance was mainly in plants accumulating very little or no $\mathrm{N}$ protein; plants accumulating high levels of the $\mathrm{N}$ protein were resistant at the local-lesions level. Vaira et al. (1995) indicated that plants with high levels of the $\mathrm{N}$ protein expression were protected against infection with unrelated virus strains as well as some other tospoviruses. In this study, two Polish TSWV strains, B and C, were used. Both are related to the BR-01 strain and belong to the I serotype, which is present in The Netherlands, Germany, and Italy (Korbin, 1995). The cassette used in this study included the DNA sequence of the $N$ gene from the Bulgarian L3 isolate that is related to Brazilian
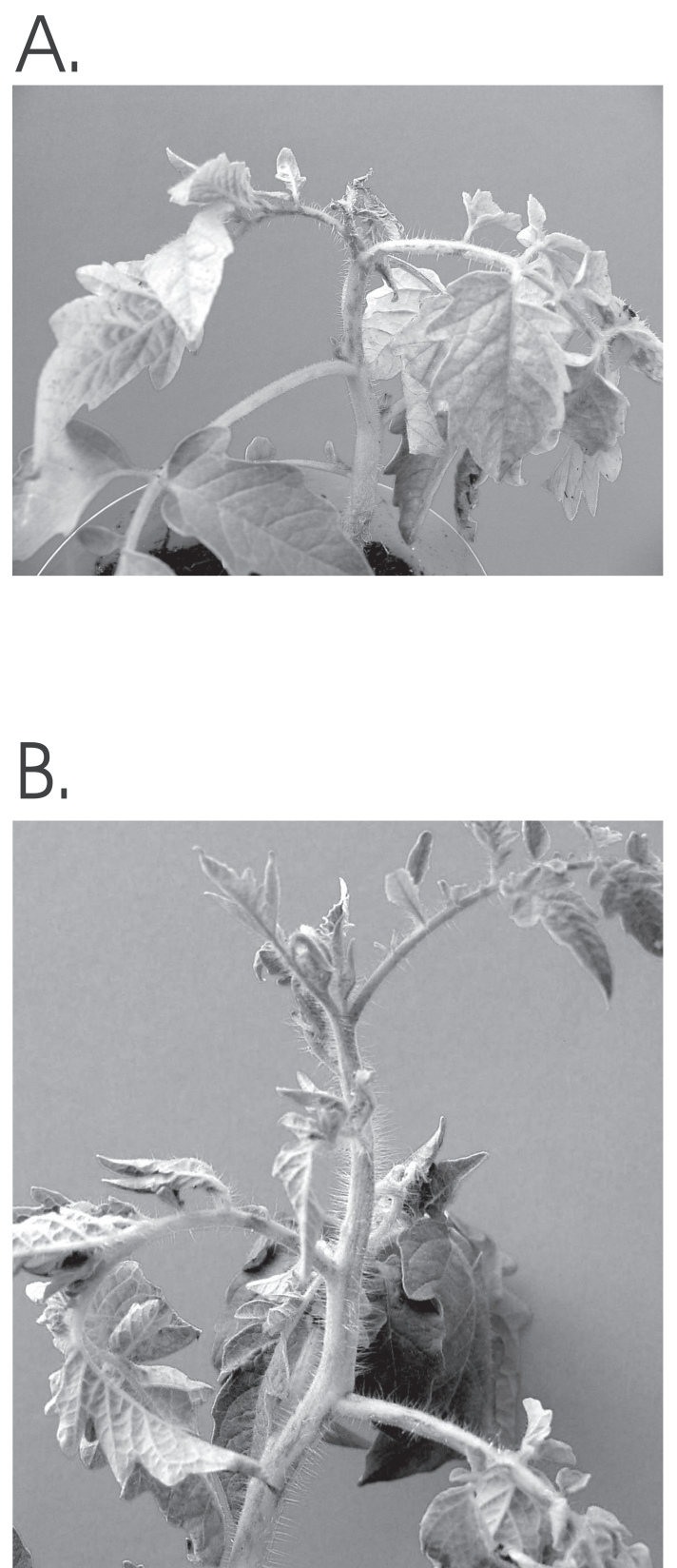

Fig. 2. (A) Transgenic tomato plants susceptible to TSWV and (B) showing the recovery reaction $20 \mathrm{~d}$ after mechanical inoculation.

TSWV strains (Maiss et al., 1991). This may explain the presence of so many plants with high levels of the protein-dependent resistance.

It is surprising that resistance was not present in all the plants expressing high levels of protein. Two plants that were susceptible to infection showed high and moderate-level of protein expression. It is possible that these plants express partial resistance that depends on certain conditions, such as plant age, growing conditions, and the inoculum concentration. Vaira et al. (1995) observed such plants. Our results and some previous studies suggest that the current models of the virus replication blockage cannot explain virus-specific resistance. High accumulation of $\mathrm{N}$ protein or $N$ gene transcripts was expected to improve resistance, but this relationship was not confirmed. Variable levels of resistance-susceptibility were observed among plants that expressed no detectable $\mathrm{N}$ protein. Probably, the susceptible plants that 




\section{EtBr stained rRNA}

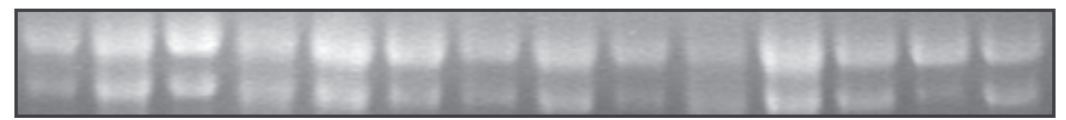

Fig. 3. Northern blot analysis of the $N$ transgene in selected transgenic tobacco plants. Total RNA was isolated from transgenic plants (20 $\mu \mathrm{g}$ per lane), blotted and probed with the $N$ gene. Lanes: 1, non-transgenic plant; 2-14, some of the transgenic plants, which were resistant to the TSWV inoculation. Transgenic plants that gave readings were rated as expressors (+). The density of the control and some transgenic plants was set at zero (-). Ethidium bromide stained rRNA was used as a control for equal loading of the RNA.

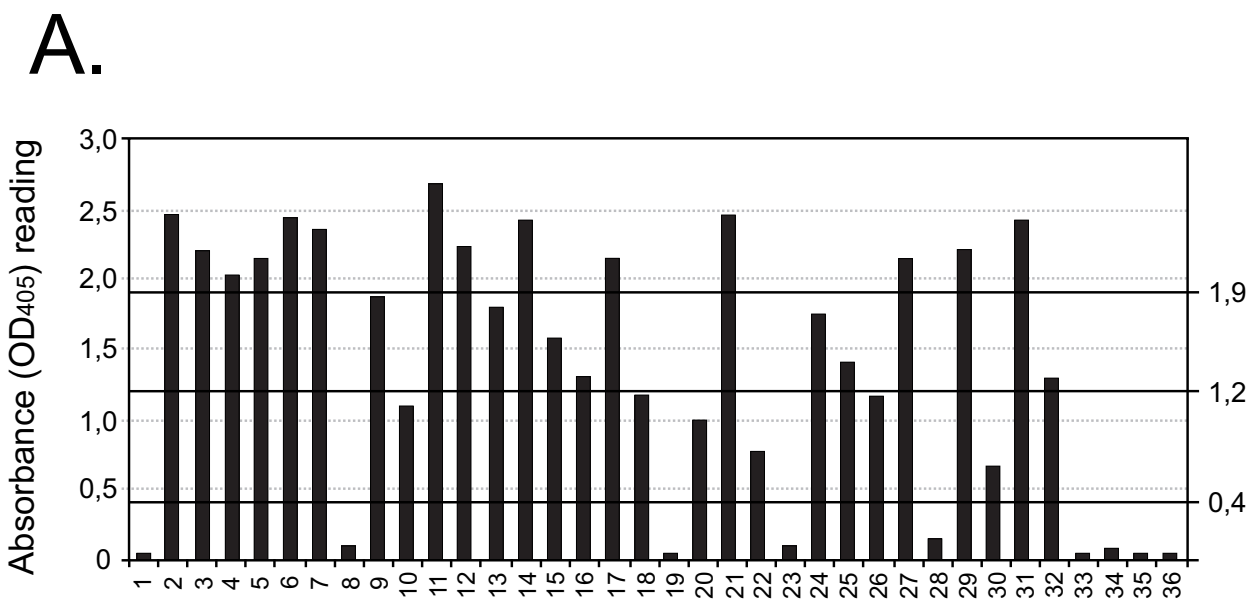

Tobacco plant number
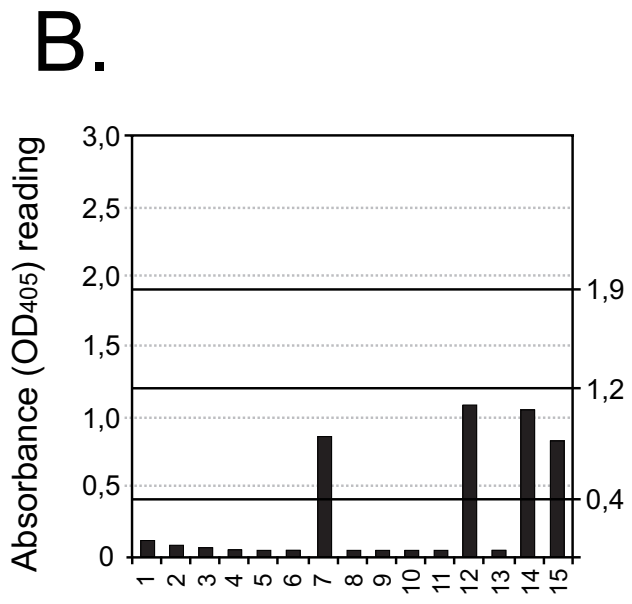

Tomato plant number

Fig. 4. The level of the nucleoprotein accumulation estimated by a double-antibody sandwich enzyme-linked immunoabsorbent assay (DAS-ELISA) in selected transgenic tobacco $(\mathbf{A})$ and tomato $(\mathbf{B})$ plants. The $\mathrm{OD}_{405}$ readings ranged from 0.04 to 2.76. Plants were classified as non-expressors when the readings were below 0.41 , as low-expressors when the readings were between 0.41 and 1.20 , as mid-expressors when $\mathrm{OD}_{405}$ were between 1.20 and 1.90 , and as high-expressors when the readings were higher than 1.9. A. Lane 1, non-transgenic control tobacco plant, 2-36 transgenic tobacco plants. B. Lanes 1-3, non-transgenic control tomato plants; $4-15$ transgenic tomato plants. 

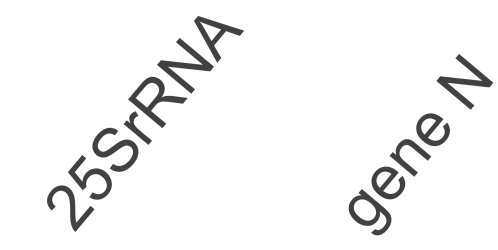

,

\section{Control N. tabaccum plant}

\section{High-expressor}

\section{Non-expressor}

Fig. 5. The nuclear run-on analysis of the $N$ gene for transgenic plants defined as non- and high expressors. Labeled nuclear RNAs were hybridized to the restriction enzyme digested $N$ gene and 25S rRNA DNA segments, which had been separated on an agarose gel and blotted onto the membrane. The nuclei used in the assay were isolated from non-transgenic control plant and from transgenic high- and non-expressor plants.

showed no detectable protein had an inactivated nucleoprotein gene (transcriptional silencing).

RNA-dependent protection is based on the post-transcriptional silencing mechanism (PTGS) (Baulcombe, 1999). This mechanism does not increase the transcription level but rather, the degradation of transcripts produced by plant as well as by the genomic and subgenomic RNAs of the infecting virus. Run-on assay analysis conducted in this study confirmed that nucleoprotein gene was actively transcribed in the nuclei but the transcripts were not detectable. This suggests that resistance of plants expressing no detectable $\mathrm{N}$ protein is caused by a post-transcriptional silencing mechanism. Resistance is induced by an over-expression of identical transcripts or by aberrant transcripts (untranslatable, intron-less, self-complementary, aberrant length) (Waterhouse et al., 1998). This phenomenon was often observed in plants with multiple transgene copies. De Carvalho et al. (1992) described that the presence of single copy of the transgene in a haploid genome induced PTGS. Our Southern-blot analyses confirmed that plants with silenced transgene had more than one insert in the genome, or inserts of truncated sequences. It should be noted that the presence of multi-copies of a transgene is not sufficient per se to induce the silencing mechanism. Some plants with protein-dependent resistance also had more than one insert of the transgene. This suggests in turn that in plants that exhibit the PTGS, all integrated copies must be transcriptionally active. In plants expressing high levels of protein, additional inserts are either inactive or active at a low level, and the amount of produced transcripts do not reach the threshold level that induces silencing.

It is unclear why some plants with the induced silencing mechanism did not show high level of resistance. In theory, the PTGS is systemically spread and once induced it permanent and leads to a complete degradation of the virus RNAs (Waterhouse et al., 1999). Measurements of the virus protein accumulation in transgenic plants over time and in different leaves clearly showed that the $N$ gene might be silenced to different degrees at different developmental stages (Pang et al., 1996). That may explain why some plants with the induced silencing mechanism showed the LL or D phenotypes.

All tomato plants with the $\mathrm{R}$ phenotype had single transgene insertions in their genomes and expressed no detectable $\mathrm{N}$ transcripts and proteins. After the viral infection and typical early stages of symptom development, the plants gradually outgrew the infection. Also the bio- and ELISA test proved the absence of the virus in R plants. This reaction may be indicative of the silencing mechanism induction. However previously described $\mathrm{R}$ plants (Lindbo et al., 1993) had 1-2 transgene copies and showed the moderate level of $N$ gene expression. During the infection, transgene transcripts and the replicating virus genome act additively to trigger the switch for the transgene mRNA silencing, resulting in the recovery phenotype in the upper leaves at a later developmental stage (Waterhouse et al., 1999). The infection scenario of the $R$ plants observed in this study was identical but the expression pattern differed from that described in the literature. The resistance is definitely RNA dependent but its mechanism remains unclear.

It should be noted that the position and orientation of the transgene integration, as well as plant factors that influence the transgene itself, play a significant role in the expression of resistance or susceptibility in transgenic plants.

\section{Literature Cited}

Bartoszewski, G., S. Malepszy, and K. Niemirowicz-Szczytt, 1996. Transformation in selected forms of the tomato Lycopersicon esculentum Mill. using Agrobacterium tumefaciens. J. Appl. Genet. 37A:97-100.

Baulcombe, D.C. 1999. Fast forward genetics based on virus-induced gene silencing. Curr. Opin. Plant Biol. 2:109-113.

Chomczynski, P. 1993. A reagent for the single-step simultaneous isolation of RNA, DNA and proteins from cell and tissue samples. Biotechniques 15:532-537.

De Carvalho, F., G. Gheysen, S. Kushnir, M. van Montague, D. Inze, and C. Castresana. 1992. Suppression of $\beta$-1,3-glucanase transgene expression in homozygous plants. EMBO J. 11:2595-2602.

De Haan, P., J.J.L. Gielen, M. Prins, I.G. Wijkamp, A. van Schepen, D. Peters, M.Q.J.M. van Grinsven, and R. Goldbach. 1992. Characterisation of RNA-mediated resistance to tomato spotted wilt virus in transgenic tobacco plants. Biotechnology 10:1133-1137.

De Haan, P., L. Wagemakers, D. Peters, and R. Goldbach. 1990. The S RNA segment of tomato spotted wilt virus has an ambisense character. J. Gen. Virol. 71:1001-1007.

Dehio, C. and J. Schell. 1994. Identification of plant genetic loci involved in posttranscriptional mechanism for meiotically reversible transgene silencing. Proc. Natl. Acad. Sci. USA 91:5538-5542.

Doyle, J.J. and J.L. Doyle. 1990. Isolation of plants DNA from fresh tissue. Focus 12:13-15.

Francki, R.I.B. and T. Hatta. 1981. Tomato spotted wilt virus, p. 491-512. In: E. Kurstak (ed.). Handbook of plant virus infections and comparative diagnosis. Elsevier/North Holland Biomedical Press, Amsterdam, The Netherlands.

Gielen, J.J.L., P. de Haan, A.J. Kool, D. Peters, M.Q.J.M. van Grinsven, 
and R.W. Goldbach. 1991. Engineered resistance to tomato spotted wilt virus, a negative-strand RNA virus. Biotechnology 9:1363-1367.

Goldbach, R. and D. Peters, 1994. Possible causes of the emergence of tospovirus diseases. Sem. Virol. 5:113-120.

Horsch, R.B., J.E. Fry, N.L. Hoffman, D. Eichholtz, S.G. Rogers, and R.T. Fraley. 1985. A simple and general method for transferring genes into plants. Science 227:1229-1231.

Jankowski, F., Z. Gajos, and A. Konczerowicz. 1963. Wyniki badań nad identyfikacją choroby powodującej kędzierzawość liści tytoniu w Lubelskim Okręgu uprawy tytoniu. Biuletyn Centralnego Laboratorium Przemysłu Tytoniowego 3-4:23-34.

Kamińska, M. and M. Korbin. 1994. Symptoms and detection of tomato spotted wilt virus in Polish glasshouses. Phytopathol. Pol. 7:93-98.

Kim, J.W., S.S.M. Sun, and T.L. German. 1994. Disease resistance in tobacco and tomato transformed with the tomato spotted wilt virus nucleocapsid gene. Plant Dis. 78:615-621.

Koncz, C. and J. Schell. 1986. The promoter of TL-DNA gene 5 controls the tissue-specific expression of chimeric genes carried by novel type of Agrobacterium binary vector. Mol. Gen. Genet. 204:383-396.

Korbin, M. 1995. Characterization and detection of Polish tomato spotted wilt virus (TSWV) isolates. The Res. Inst. Pomol. Floricult., Skierniewice, Poland, PhD thesis.

Landsmann, J., D. Lewellyn, E.S. Dennis, and W.J. Peacock. 1988. Organ regulated expression of the Parasponia andersonii haemoglobin gene in transgenic tobacco plants. Mol. Gen. Genet. 214:63-73.

Lindbo, J.A., L. Silva-Rosales, and W.G. Dougherty. 1993. Pathogenderived resistance to potyviruses: Working, but why? Sem. Virol. 4:369-379.

MacKenzie, D.J. and P.J. Elis. 1992. Resistance to tomato spotted wilt virus infection in transgenic tobacco expressing the viral nucleocapsid gene. Mol. Plant-Microbe Interac. 5:34-40.

Maiss, E., L. Ivanova, E. Breyel, and G. Adam. 1991. Cloning and sequencing of the S RNA from a Bulgarian isolate of tomato spotted wilt virus. J. Gen. Virol. 72:461-464.

McCormick, S. 1991. Transformation of tomato with Agrobacterium tumefaciens, B6 p. 1-9. In: K. Lindsey (ed.). Plant tissue culture manual: Fundamentals and applications. Kluwer Academic Publishers. Dordecht, The Netherlands.

Murashige, T. and F. Skoog. 1962. Arevised medium for rapid growth and bioassays with tobacco tissue culture. Physiol. Plant. 15:473-497.

Pang, S.Z., F.J. Jan, K. Carney, J. Stout, D.M. Tricoli, H.D. Quemade, and D. Gonsalves. 1996. Post-transcriptional transgene silencing and consequent tospovirus resistances in transgenic lettuce affected by transgene dosage and plant development. Plant J. 9:899-909.

Pang, S.Z., P. Nagpala, M. Wang, J.L. Slightom, and D. Gonsalves. 1992. Resistance to heterologous isolates of tomato spotted wilt virus in transgenic tobacco expressing its nucleocapsid gene. Phytopathology 82:1123-1229.

Pang, S.Z., J.L. Slightom, and D. Gonsalves. 1993. Different mechanisms project transgenic tobacco against tomato spotted wilt and impatiens necrotic spot Tospoviruses. Biotechnology 11:819-825.

Prins, M. and R. Goldbach. 1998. The emerging problem tospovirus infection and nonconventional methods of control. Trends in Microbiol. 6:31-35.

Rosello S., M.J. Diez, and F. Nuez. 1996. Viral diseases causing the greatest economic losses to the tomato crop. I. The tomato spotted wilt virus. Scientia Hort. 67:117-150.

Rusinowski Z., M. Śmiech, M. Kamińska, and K. Niemirowicz-Szczytt. 2002. Identification of Lycopersicon spp. hybrids on the basis of morphological and molecular (RAPD) properties as well as evaluation of resistance to tomato spotted wilt virus (TSWV). Acta Soc. Bot. Pol. 71:109-114.

Sakimura, K. 1962. The present status of thrips-borne viruses, p. 33-40. In: K. Maramorosh (ed.). Biological transmission of disease agents. Academic, New York.

Sambrook, J., E.F. Fritsch, and T. Maniatis. 1989. Molecular Cloning. A laboratory manual, 2nd ed. Cold Spring Harbor Laboratory Press, Cold Spring Harbor, N.Y.

Seroczyńska, A., K. Niemirowicz-Szczytt, and A. Korzeniewska. 1998. Utilization of three non-ripening mutants in tomato breeding for prolonged shelf life. Folia Hort. 10:3-14.

Smith, K.M. 1932. Studies on plant virus diseases XI. Further experiments with a ringspot virus. Its identification of spotted wilt of the tomato. Ann. Appl. Biol. 19:305-330.

Stoeva, P., M. Yankulova, V. Nikolaeva, R. Bachvarova, L. Ivanova, E. Maiss, G. Adam, V. Vulkov, S. Guelemerov, and A. Atanassov. 1998. Long-term resistance to tomato spotted wilt virus in transgenic tobacco cultivars expressing the viral nucleoprotein gene: greenhouse and field tests. Mol. Breed. 4:155-164.

Ultzen, T., J. Gielen, F. Venema, A. Westerbroek, P. de Haan, M.L. Tan, A. Schram, M. van Grinsven, and R. Goldbach. 1995. Resistance to tomato spotted wilt virus in transgenic tomato hybrids. Euphytica 85:159-168.

Vaira, A.M., L. Semeria, S. Crespi, V. Lisa, A. Allavena, and G.P. Accotto. 1995. Resistance to Tospoviruses in Nicotiana benthamiana transformed with the $N$ gene of tomato spotted wilt virus: correlation between transgene expression and protection in primary transformants. Mol. Plant-Microbe Interac. 8:66-73.

Waterhouse, P.M, M.W. Graham, and M.B. Wang. 1998. Virus resistance and gene silencing in plants can be induced by simultaneous expression of sense and antisense RNA. Proc. Natl. Acad. Sci. USA 95:13959-13964.

Waterhouse, P.M., N.A. Smith, and M.B. Wang. 1999. Virus resistance and gene silencing: Killing the messenger. Trends in Plant Sci. 4:452-457.

Wijkamp, I., J. van Lent, R. Kormelink, R.W. Goldbach, and D. Peters. 1993. Multiplication of tomato spotted wilt virus in its insect vector, Frankliniella occidentalis. J. Gen. Virol. 74:341-349. 